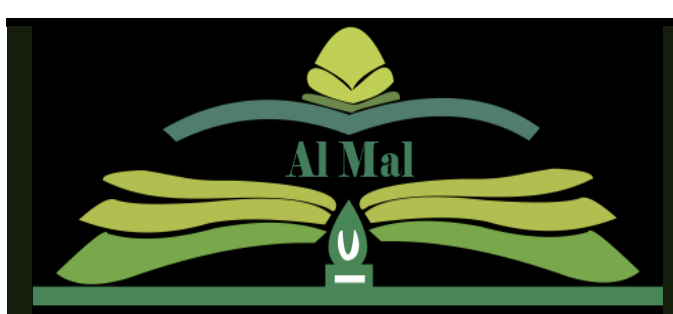

Jurnal Akuntansi dan Keuangan Islam
Al-Mal: JurnalAkuntansi dan Keuangan Islam E-ISSN: 2715-9477, P-ISSN: 2751-954X Volume 03 Issue 01, 21 Januari 2022 Journal Page is available to: http://ejournal.radenintan.ac.id/index.php/al-mal/index

\title{
Analisis Kesesuaian Perlakuan Akuntansi Murabahah Berdasarkan PSAK 102 Di BMT Usaha Artha Sejahtera
}

\begin{tabular}{l} 
Surepno \\
$\mathbf{1}^{*}, 2$ Departement of Economics, F \\
Agama Islam Negeri Kudus, Ind \\
\hline \multicolumn{1}{c}{ ARTICLE INFO } \\
\hline Article history: \\
Received 19-01-2022 \\
Revised 20-01-2022 \\
Accepted 21-01-2022 \\
Available 21-01-2022 \\
Revised (1) 24-07-2022 \\
Accepted 31-07-2022 \\
Revised Available 01-08-2022 \\
\hline Kata Kunci: \\
Perlakuan Akuntansi, Murabahah, \\
dan Standar Akuntansi
\end{tabular}

Paper type: Research paper

Please cite this article: Surepno, $\mathrm{S}$., \& Inayah, N. "Analisis Kesesuaian Perlakuan Akuntansi Murabahah Berdasarkan PSAK 102 Di BMT Usaha Artha Sejahtera" Al-Mal: Jurnal Akuntansi dan Keuangan Islam [ONLINE], Volume 03 Number 01 (Januari 21, 2022)

\section{Cite this document:} Al-Mal 2th edition

\section{*Corresponding author}

e-mail: surepno@iainkudus.ac.id

\begin{tabular}{l}
\hline ABSTRAK \\
\hline Penelitian ini bertujuan untuk menganalisis \\
perlakuan akuntansi murabahah pada BMT Usaha \\
Artha Sejahtera yang disesuaikan dengan PSAK \\
102. Jenis penelitian yang digunakan dalam \\
penelitian ini adalah penelitian kualitatif dengan \\
pendekatan studi kasus. Teknik pengumpulan data \\
yang digunakan terdiri dari wawancara dan \\
dokumentasi. Hasil penelitian menunjukkan bahwa \\
masih ada perlakuan akuntansi yang belum \\
sepenuhnya sesuai dengan PSAK 102 yaitu saat \\
terjadi pengakuan dan pengukuran aset murabahah \\
BMT Usaha Artha Sejahtera tidak melakukan \\
pengakuan aset murabahah sebesar harga \\
perolehan barang, tidak menggunakan rumus \\
tertentu dalam menentukan margin murabahah, \\
BMT tidak mengenakan denda kepada nasabah \\
tetapi memberikan surat teguran sesuai dengan \\
kebijakan pihak BMT. Keterbatasan pada penelitian \\
ini yaitu objek pengamatan penelitian terfokus \\
pada BMT sehingga membuka peluang bagi \\
peneliti selanjutnya untuk menambahkan objek \\
yang lebih luas. Implikasi Pada penelitian ini yaitu \\
penyajian piutang murabahah tidak disajikan di \\
neraca sebesar nilai bersih yang \\
dapat direalisasikan, tetapi menjadi satu dengan \\
akad piutang yang lainnya sebagai piutang dan \\
pembiayaan, margin murabahah tangguhan tidak \\
diungkapkan sebagai pengurang piutang \\
murabahah, namun dicatat sebagai piutang dan \\
pembiayaan dan pihak BMT tidak mengungkapkan \\
margin murabahah, namun diungkapkan jadi satu \\
dengan akad pembiayaan yang lainnya sebagai \\
bagi hasil pembiayaan. \\
Al-Mal with CC BY license. Copyright $\odot 2022$, the author(s) \\
\hline
\end{tabular}




\begin{abstract}
This study aims to analyze the accounting treatment of murabahah at BMT Usaha Artha Sejahtera which is adjusted to PSAK 102. The type of research used in this study is a qualitative research with a case study approach. Data collection techniques used consisted of interviews and documentation. The results show that there is still accounting treatment that is not fully in accordance with PSAK "102, namely when there is recognition and measurement of murabahah assets BMT Usaha Artha Sejahtera "does not recognize murabahah assets at the cost of goods, does not use certain formulas in determining murabahah margins, BMT" does not impose a fine on the customer but provides a letter of warning in accordance with the policy of the BMT. The limitation of this research is that the object of research observation is focused on BMT so that it opens up opportunities for further researchers to add a wider object. The implication of this research is that the presentation of "murabahah receivables is not presented in the balance sheet at the net value that can be "realized, but "integrated with other receivables as receivables" and financing, "deferred murabahah margin is not disclosed as a deduction from murabahah receivables, but is recorded as receivables and financing and the BMT did not disclose the murabahah margin, but disclosed it together with another financing contract as a profit sharing "financing".
\end{abstract}

Keyword: Accounting Treatment, Murabaha, and Accounting Standards.

\title{
PENDAHULUAN
}

Di Indonesia, ekonomi syariah dimulai pada tahun 1991 dengan berdirinya Bank Muamalat Indonesia (BMI), yang diikuti dengan munculnya lembaga keuangan syariah lainnya. Koperasi Syariah atau Baitul Mal Wa Tamwil adalah lembaga keuangan yang memposisikan diri untuk usaha kecil dan mikro (BMT) dan Koperasi Jasa Keuangan Syariah adalah lembaga keuangan yang memposisikan diri (KJKS). Karena hukum koperasi adalah syariah, BMT harus mematuhi undang-undang no. 25 Tahun 1992 tentang Perkoperasian, serta Keputusan Menteri Koperasi dan UKM Nomor: 91/Kep/M.UKM/IX/2004 tentang Pedoman Pelaksanaan Kegiatan Usaha Koperasi dan Jasa Keuangan (Rifqi Muhammad, 2008).

Produk penghimpunan dan penyaluran dana yang dapat dikembangkan oleh lembaga keuangan syariah, termasuk BMT. BMT memberikan pembiayaan berdasarkan jual beli (al bai') yaitu murabahah, prinsip sewa atau multijasa (ijarah), prinsip kemitraan (partnership), yaitu prinsip penyertaan (musyarakah), prinsip bagi hasil (mudharabah) dan (al qordhul hasan). Pedoman 
dalam penyajian laporan keuangan syariah terutama BMT diatur dalam Pernyataan Standar Akuntansi (PSAK) No. 59 Akuntansi Perbankan Syariah yang dikeluarkan oleh Dewan Standar Akuntansi Keuangan (DSAK) dari Ikatan Akuntansi Indonesia (IAI) pada tanggal 1 Mei 2002. Dalam perjalannnya, aturan akuntansi Syariah terus berkembang. Pada tahun 2007, peraturan transaksi Syariah PSAK 59 direvisi dan dirinci dalam PSAK 101-110. Akuntansi murabahah diatur oleh PSAK102 untuk akuntansi, pengukuran, penyajian dan pengungkapan transaksi murabahah baik untuk penjual maupun pembeli (Sofyan Safri Harapah, Wiroso, dkk, 2010).

Keberadaan PSAK Syariah sudah menjadi kebutuhan seiring dengan pesatnya perkembangan lembaga keuangan syariah. Suatu lembaga keuangan syariah membutuhkan pedoman dalam pelaporan aktivitasnya yang menjadi acuan dalam menilai profesionalitas dan kualitas dari lembaga keuangan syariah tersebut. PSAK Syariah yang baik akan mendorong terciptanya sistem akuntansi yang baik pula, sehingga akan tersedia informasi yang dapat dipercaya dan kredibel. Kemudian, ketersedian informasi tersebut akan menjadi pedoman bagi para stakeholders (pemangku kepentingan) dalam pengambilan keputusan ekonomi (Mughni, 2019).

Murabahah merupakan praktik ekonomi yang menggunakan nilai syariah. Murabahah dapat dipahami sebagai pembelian dan penjualan barang, dan dapat digunakan untuk menghitung harga beli dan margin keuntungan yang disepakati antara penjual dan pembeli. Pembayaran akad jual beli dapat dilakukan secara tunai dan kredit. Perbedaan murabahah dari jual beli seperti yang kita ketahui adalah bahwa penjualan langsung memberitahu pembeli harga pokok barang dan keuntungan yang mereka inginkan. Saat menukar barang dengan barang, pastikan untuk mempertimbangkan apakah barang tersebut ribawi atau bukan. Jika pertukaran barang ribawi akan dilakukan, maka harus dilakukan dalam jumlah yang sama dan harus dilakukan dari tangan ke tangan atau dari tunai ke tunai (Sri Nurhayati, Wasilah, 2015). 
Penelitian yang dilakukan oleh Ningrum (2019) menunjukan implementasi akuntansi terkait pengakuan, pengukuran, penyajian dan pengungkapan piutang murabahah pada KSSP BMT Ummah Surabaya belum sepenuhnya sesuai berdasarkan dengan ketentuan PSAK No. 102. Penelitian yang dilakukan oleh Masruroh (2019) menunjukkan ada beberapa yang belum diterapkan oleh BMT Salafiah di kabupaten Situbondo sehingga masih ada yang belum sesuai dengan PSAK 102 seperti penerapan, perolehan aset murabahah dan denda murabahah. Adapun penelitian lain yang dilakukan oleh (Ernawati, 2020) menunjukkan hasil bahwa praktik akuntansi murabahah dalam transaksi pembiayaan terkait dengan pengakuan, pengukuran, pelaksanaan dan pengungkapan transaksi akuntansi murabahah pada BMT Maslahah Capem Diwek tidak sesuai dengan PSAK 102.

Penelitian yang dilakukan oleh (Pratiwi \& Septiarini, 2014) menyatakan bahwa dalam hal pengakuan, pengukuran, penyajian, dan pengungkapan terhadap transaksi awal akad murabahah tidak sesuai dengan PSAK 102. Penelitian lain yang dilakukan oleh Astika (2018) menunjukkan bahwa penerapan akuntansi syariah berdasarkan PSAK 102 pada pembiayaan murabahah di PT Bank BNI Syariah Cabang Makassar belum sepenuhnya sesuai dengan PSAK 102 terhadap denda bagi nasabah yang terlambat membayar diterima dan diakui sebagai dana kebajikan. Adapun penyajian, pengungkapan, pengakuan dan pengukuran terkait pengakuan persediaan, diskon pembelian, keuntungan murabahah, potongan murabahah, uang muka telah sesuai aturan PSAK 102.

Penelitian yang dilakukan oleh Ahmad Firmansyah (2016) menunjukkan bahwa penerapan pembiayaan murabahah yang terjadi di PT BRI syariah cabang bululawang malang dan BMT bululawang malang masalahah belum sesuai dengan prinsip syariah. Demikian terdapat penelitian yang sesuai dengan PSAK 102 oleh As'ad (2017) menunjukkan bahwa perlakuan akuntansi yang meliputi pengakuan, pengukuran, penyajian dan pengungkapan sudah hampir seluruhnya sesuai dengan PSAK 102. Namun, masih ada beberapa yang 
belum sesuai dengan PSAK 102 seperti pengakuan uang muka dan perolehan aset murabahah.

Penelitian lain yang menunjukkan hasil berbeda adalah penelitian oleh (Oktafiya \& Iswanaji, 2020) menunjukkan bahwa perlakuan akuntansi terhadap pembiayaan murabahah yang dilakukan pada BMT ARMA sudah sesuai dengan prinsip akuntansi yaitu PSAK 102. Selain itu, penelitian yang dilakukan oleh (Yusuf, 2013) menunjukkan bahwa dalam hal perlakuan akuntansi atas transaksi Murabahah pada Bank Syariat X sudah sesuai dengan PSAK 102 tentang Akuntansi murabahah, namun dalam mengimplementasikan pembiayaan murabahah, hanya berdasarkan pesanan saja, sedangkan pada PSAK No. 102 murabahah dapat dilakukan berdasarkan atau tanpa pesanan. Adapun penelitian oleh (Latifah, 2021) menyatakan bahwa perlakuan akuntansi pembiayaan murabahah di KSPPS BMT Mandiri Sejahtera Jawa Timur sebagian besar telah dijalankan sesuai dengan PSAK 102 baik kesesuaian pada pengakuan perolehan, pengakuan keuntungan.

Penelitian-penelitian tersebut menjelaskan bahwa PSAK 102 dalam prakteknya belum diterapkan secara penuh. Lembaga keuangan syariah termasuk BMT wajib menggunakan pedoman yang telah ditetapkan oleh Dewan Standar Akuntansi Syariah (DSAS) IAI dalam hal ini PSAK No. 102. Ketidaksesuaian praktik perlakuan akuntansi dengan PSAK di lapangan menimbulkan keinginan untuk mengetahui perlakuan akuntansi murabahah di BMT Usaha Artha Sejahtera apakah sudah sesuai atau tidak dengan PSAK No. 102.

Kinerja Sharia enterprise theory merupakan enterprise theory yang telah dimasukkan nilai-nilai keislaman di dalamnya. Sharia enterprise theory menyatakan bahwa akuntanbilitas diciptakan tidak hanya untuk perusahaan, tetapi untuk seluruh pemangku kepentingan. Pertanggung jawaban yang dimaksud adalah pertanggungjawaban yang vertikal dan horizontal. Hal ini menunjukkan bahwa, terdapat keseimbangan antara kesejahteraan ekonomi, sosial, dan spiritual. Sumber hidayah yang dimiliki oleh para stakeholders pada 
dasarnya adalah amanah dari Allah yang di dalamnya melekat sebuah tanggug jawab untuk menggunakan dengan cara dan tujuan yang ditetapkan oleh sang pemberi amanah. (M. Ali Rusdi dan Fikri, 2019).

Mutia mengemukakan terdapat beberapa prinsip yang menggambarkan adanya interaksi antara manusia dan penciptanya yaitu Allah SWT. Prinsipprinsip ini merupakan berbagi yang adil, rahmatan lilalamin (rahmat bagi seluruh alam), dan maslahah (kepentingan masyarakat). Menurut Al-Ghazali, prinsip-prinsip ini sebenarnya mempunyai hubungan dengan tujuan ekonomi syariah yang memprioritaskan kepentingan masyarakat. (Anggraeni, 2019).

Jual beli adalah tukar menukar sesuatu dengan lainnya, sedangkan menurut istilah, jual beli adalah perikatan yang mengandung pengertian pertukaran harta benda atau jasa dengan harta benda lain untuk selamalamanya. Prinsip-prinsip jual beli dilaksanakan sehubungan dengan adanya perpindahan kepemilikan barang yang terkenal digunakan oleh lembaga keuangan syariah termasuk salah satunya BMT adalah pembiayaan murabahah (Muslim, 2015). Pembiayaan (financing) adalah pendanaan yang diberikan oleh suatu pihak kepada pihak lain untuk mendukung investasi yang telah direncanakan, baik dilakukan sendiri maupun lembaga atau dengan kata lain pembiayaan adalah pendanan yang dikeluarkan untuk mendukung investasi yang telah direncanakan (Parno \& Tikawati, 2016).

Akad murabahah adalah transaksi jual beli barang, dimana penjual mengungkapkan harga perolehan kepada pembeli dan memperoleh keuntungan berdasarkan margin yang telah disepakati oleh kedua belah pihak (Purnama \& Putra, 2018). Murabahah adalah jasa pembiayaan dengan mengambil bentuk transaksi jual beli dengan cara cicilan, yaitu penjual membeli barang yang dibutuhkan dari pemasok, kemudian menjualnya kepada pembeli dengan cicilan yang disepakati antara penjual dan pembeli (Muslim, 2015). Menurut Sri Nurhayati (2011: 168) dalam (Wardani, 2017) murabahah merupakan transaksi penjualan dengan menyatakan harga perolehan dan 
keuntungan yang disepakati oleh penjual dan pembeli, pembayaran atas akad dapat dilakukan secara tunai atau tangguh.

Murabahah untuk bank syariah adalah sebagai salah satu bentuk penyaluran dalam mengumpulkan dana untuk mendapatkan penghasilan dalam bentuk margin. Bagi pelanggan yang menerima fasilitas, manfaatnya adalah merupakan suatu cara untuk mendapatkan komoditas tertentu melalui pembiayaan bank. Dalam jual beli melalui pembiayaan murabahah, pembayaran cicilan yang dilakukan oleh pelanggan tidak akan berubah selama periode perjanjian (Albana \& Firmansyah, 2021). Aplikasi murabahah dalam perbankan syariah dapat dikategorikan pada pembiayaan konsumtif dan pembiayaan produktif. Pembiayaan konsumtif merupakan pembiayaan untuk keperluan konsumsi nasabah, antara lain pembelian rumah, motor dan keperluan konsumsi keseharian lainnya. Sedangkan, untuk pembiayaan produktif adalah pembiayaan yang terkait dengan modal kerja dan investasi (Susilowati \& Sofi'i, 2018).

Adapun, syarat-syarat murabahah menurut Antonio (2003:102) dalam (Nasir \& Sululing, 2015), antara lain: (1) Penjual memberi tahu biaya modal kepada nasabah; (2) Kontrak pertama harus sah sesuai dengan rukun yang ditetapkan; (3) Kontrak harus bebas dari riba'; (4) Penjual harus menjelaskan kepada pembeli bila terjadi cacat atas barang sesudah pembelian; (5) Penjual harus menyampaikan semua hal yang berkaitan dengan pembelian, misalnya jika pembelian dilakukan secara hutang. Dilihat dari aspek jenisnya, murabahah dibagi menjadi dua bagian, yaitu (Hidayah et al., 2021) :

a. Murabahah tanpa pesanan, artinya ada yang beli atau tidak, pihak Bank Syariah menyediakan barang.

b. Murabahah berdasarkan pesanan, terjadi dengan cara penjual melakukan pembelian barang setelah ada pemesanan dari pembeli. Menurut (Septyarini, 2018) murabahah dengan pesanan dapat bersifat mengikat atau tidak mengikat pembeli untuk membeli barang yang dipesannya. 
Menurut (Novianti et al., 2020) hal yang membedakan murabahah dengan penjualan yang lainnya ialah penjual secara jelas memberi tahu kepada pembeli berapa harga pokok barang tersebut dan berapa besar keuntungan yang diinginkannya. Dalam pengambilan keuntungan tersebut besarnya keuntungan yang diharapkan harus jelas dan transparan, dengan menyatakan harga perolehan dan keuntungan yang diharapkan. Sehingga, keuntungan tersebut lebih bersifat margin atau sesuatu yang disepakati bukan dalam bentuk mark up tambahan yang lebih dekat pada bentuk pendzaliman, sebab ditentukan sepihak tanpa analisis yang rasional (Fasiha, 2015).

\section{METODOLOGI PENELITIAN}

Penelitian ini adalah pendekatan kualitatif dengan metode studi kasus. Penelitian ini menggambarkan serta menjelaskan perlakuan akuntansi murabahah pada Baitul Maal wa Tamwil. Pendekatan kualitatif studi kasus merupakan satu-satunya cara andal dan relevan untuk bisa memahami fenomena sosial (tindakan manusia). Yang akan dipecahkan lebih lanjut, menggunakan metode kualitatif karena dengan metode kualitatif lebih sensitif (aktif-reaktif dan dapat diadaptasi). Penelitian kualitatif merupakan jenis penelitian yang temuan-temuannya tidak diperoleh melalui prosedur statistik atau bentuk hitungan lainnya. (Sugiarto, 2015) Metode dalam pengumpulan data dalam penelitian studi kasus yang digunakan pada penelitian ini adalah sebagai berikut:

\section{Metode Observasi}

Metode observasi (pengamatan) adalah teknik yang dilakukan secara langsung dan pencatatan secara otomatis terhadap fenomena yang diselidiki. Karena penelitian yang dilakukan adalah termasuk jenis penelitian kualitatif, maka observasi yang penulis lakukan dalam penelitian ini adalah observasi terus terang. Dalam hal ini, peneliti dalam mengumpulkan data menyatakan terus terang kepada sumber data, bahwa peneliti sedang melakukan penelitian. penulis juga menggunakan 
observasi partisipasif, yaitu peneliti datang ditempat penelitian serta ikut terlibat dalam kegiatan di tempat penelitian. Metode ini peneliti gunakan untuk memperoleh data secara langsung tentang analisis perlakuan akuntansi murabahah berdasarkan PSAK 102 pada KSPPS BMT Usaha Artha Sejahtera. Dalam metode ini, peneliti mengamati kondisi fisik, mengamati letak geografis, mengamati kegiatan operasional serta mengamati sarana prasarana yang ada di KSPPS BMT Usaha Artha Sejahtera.

2. Metode Wawancara

Metode pengumpulan data dengan cara melakukan tanya jawab lisan kepada pihak yang akan diteliti, yaitu manajer BMT usaha artha sejahtera. Wawancara bisa mengambil beberapa bentuk yang paling umum dengan bentuk wawancara studi kasus bertipe open-ended, dimana peneliti dapat bertanya kepada responden kunci tentang fakta-fakta suatu peristiwa di samping opini mereka mengenai peristiwa yang ada, kedua tipe wawancara yang terfokus, dimana responden menjawab pertanyaan dalam waktu yang pendek, ketiga tipe wawancara secara terstruktur sejalan dengan survei. Teknik pengumpulan data ini mendasarkan diri pada laporan tentang diri sendiri atau self-report, atau setidak-tidaknya pada pengetahuan dan atau keyakinan pribadi. Adapun objek wawancara pada penelitian ini adalah pihak BMT UAS yang berkaitan dengan akuntansi murabahah.

3. Metode Dokumentasi

Metode pengumpulan data berdasarkan pada dokumen-dokumen tentang perlakuan akuntansi murabahah yang ada pada BMT UAS dan laporanlaporan lainnya yang terkait dengan masalah penelitian, sehingga dokumen tersebut mendukung dan menambah bukti dari sumber-sumber lain. 


\section{Rekaman Arsip}

Data penelitian studi kasus yang berasal dari hasil rekaman arsip juga tidak kalah penting dengan jenis data lainnya. Rekaman arsip ini biasanya berbetuk digital, yang menyangkut rekaman pelayanan, periode waktu tertentu, jumlah customer, rekaman organisasi seperti bagan, anggaran, peta, karakteristik geografis, data survei, dan sejenisnya. Rekamanrekaman arsip ini dan lainnya dapat digunakan bersama-sama dengan sumber-sumber informasi yang lain dalam pelaksanaan studi kasus. Namun demikian, tak seperti dokumenter, kegunaan rekaman arsip akan bervariasi pada satu stud kasus dan lainnya. Rekaman tersebut begitu penting sehingga bisa menjadi obyek perolehan kembali dan analisis yang luas.

\section{HASIL DAN PEMBAHASAN}

Berdasarkan analisis laporan keuangan BMT maka peneliti mendeskripsikan pengakuan dan pengukuran terkait jurnal yang dilakukan oleh BMT usaha Artha Sejahtera yaitu sebagai berikut:

1. Aset Murabahah

Pihak BMT tidak melakukan pengakuan aset murabahah sebesar harga perolehan barang, karena semua transaksi dilakukan dengan akad wakalah sehingga pihak nasabah sendiri yang melakukan pembelian barang atau berupa pembiayaan. Transaksi murabahah yang terjadi di BMT Usaha Artha Sejahtera merupakan transaksi pembiayaan, sehingga menyebabkan tidak adanya pengakuan aktiva berupa persediaan barang dagangan.

2. Piutang Murabahah

Murabahah diakui sebesar harga jual yaitu harga pokok ditambah dengan margin/keuntungan yang sudah disepakati bersama oleh pihak nasabah dan pihak BMT. 
3. Pengakuan Margin Murabahah

BMT Usaha Artha Sejahtera tidak menggunakan rumus tertentu dalam mengambil keputusan menentukan margin murabahah atau tidak menentukan besaran persentase margin murabahah yang diambil dari harga perolehan. BMT Usaha Artha Sejahtera memahami hal ini dengan konsep jual beli sehingga BMT mengacu pada target profit yang akan dicapai dan berdasarkan kesepakatan antara BMT dan nasabah.

4. Pengauan Potongan Pelunasan Piutang Murabahah

Apabila sebelum jangka waktu pelunasan angsuran tersebut jatuh tempo nasabah melakukan pelunasan dini atau percepatan pelunasan pembayaran angsuran maka nasabah berhak mendapat potongan pembayaran pelunasan dipercepat. Dalam hal ini pihak BMT mengakui sebagai sistem putus bunga sehingga nasabah hanya membayar kekurangan pokok dan bulanan yang berjalan.

Akuntansi berdasarkan PSAK 102 mencatat pada saat potongan pelunasan piutang murabahah yang diberikan kepada pembeli yang melunasi tepat waktu atau lebih cepat dari waktu yang disepakati diakui sebagai pengurang keuntungan murabahah.

Hal ini sesuai dengan penelitian yang dilakukan oleh (Ardha \& Rahman, 2013) yang menyatakan bahwa BRI Syariah cabang Kota Malang telah menerapkan perlakuan akuntansi untuk diskon pembelian, potongan pelunasan piutang murabahah, denda kepada nasabah dan uang muka dengan sesuai peraturan dalam PSAK 102. BRI Syariah mengakui diskon pembelian sebagai hak dari nasabah apabila diskon tersebut diberikan pemasok sebelum akad murabahah disepakati, dan diskon pembelian akan dibagi sesuai kesepakatan antara BRI Syariah dan nasabah apabila diskon tersebut diberikan pemasok setelah akad murabahah disepakati.

Namun, terdapat perbedaan hasil penelitian yang dilakukan oleh (Sahara \& Rahmasari, 2018) yang menyatakan bahwa dalam hal pengakuan dan pengukuran, yaitu saat penerapan diskon murabahah, implementasinya 
PT BPRS Syarikat Madani Cabang Tanjungpinang tidak mengakui adanya diskon murabahah sehingga tidak melakukan pencatatan apapun atau tidak adanya perlakuan akuntansi terkait diskon murabahah.

5. Pengakuan Denda

Apabila nasabah tidak dapat memenuhi piutang murabahah sesuai yang diperjanjikan maka pihak BMT tidak mengenakan denda kepada nasabah tetapi memberikan surat teguran sesuai dengan kebijakan pihak BMT dan diketahui penyebab nasabah belum membayar piutang tersebut.

Transaksi akuntansi murabahah berdasarkan PSAK 102 mencatat pada saat denda dikenakan jika pembeli lalai dalam melakukan kewajibannya sesuai dengan akad, dan denda yang diterima diakui sebagai dana kebajikan.

Hal ini sesuai dengan penelitian yang dilakukan oleh (Rosiyana et al., 2022) yang menunjukkan bahwa dalam penerapan akuntansi murabahah pada BMT Al-Islah tentang pengakuan, pengukuran, penyajian dan pengungkapan sepenuhnya sudah sesuai dengan ketentuan berdasarkan PSAK 102, walaupun ada beberapa hal yang belum sesuai dengan PSAK 102, yaitu ketidaksesuaian ada pada saat terjadi tunggakan angsuran dan penerimaan tunggakan angsuran tidak mencatat jurnal apapun sedangkan dalam ketentuan PSAK 102 pada saat terjadi tunggakan angsuran, margin diakui proposional dengan kas yang diterima.

Namun, terdapat perbedaan hasil penelitian yang dilakukan oleh (Putri \& Praptoyo, 2020) yang menyatakan bahwa pada BMT UGT Sidogiri Pasuruan tidak menerapkan denda karena pihak BMT berpendapat bahwa jika denda tidak termasuk syariah, maka tidak sesuai dengan perlakuan akuntansi pembiayaan murabahah berdasarkan PSAK 102. Yang dimaksud denda adalah tunggakan yang harus dibayar karena telat bayar atau pembayaran dilakukan melebihi batas jatuh tempo yang telah ditentukan. 
6. Pengakuan Uang Muka (Urbun)

Pihak BMT Usaha Artha Sejahtera tidak memberlakukan uang muka atas murabahah yang digunakan sebagai pembayaran pembelian barang. Sedangkan transaksi akuntansi murabahah berdasarkan PSAK 102 mencatat pada saat akad murabahah, barang diserahkan ke nasabah senilai harga perolehan setelah dikurangi uang muka tersebut dan margin yang disepakati dan diakui sebagai piutang murabahah.

Setelah mengetahui praktik perlakuan akuntansi yang dilakukan oleh BMT Usaha Artha Sejahtera dari hasil wawancara yang telah diolah oleh penulis, maka penulis akan menyajikan tabel terkait laporan keuangan dan keseluruhan perlakuan akuntansi murabahah di BMT Usaha Artha Sejahtera apakah perlakuan akuntansi murabahah pada BMT Usaha Artha Sejahtera telah sesuai dengan prinsip akuntansi yang berlaku umum, yaitu PSAK 102 tentang akuntansi murabahah.

Tabel 1 Pengakuan dan Pengukuran Akuntansi Murabahah

\begin{tabular}{|c|l|l|}
\hline No & \multicolumn{1}{|c|}{$\begin{array}{c}\text { Perlakuan Akuntansi pada BMT Usaha } \\
\text { Artha Sejahtera }\end{array}$} & \multicolumn{1}{|c|}{$\begin{array}{l}\text { Perlakuan Akuntansi } \\
\text { Berdasarkan PSAK 102 }\end{array}$} \\
\hline 1. & $\begin{array}{l}\text { Pihak BMT tidak melakukan pengakuan } \\
\text { aset murabahah sebesar harga perolehan } \\
\text { barang }\end{array}$ & $\begin{array}{l}\text { Persediaan pada transaksi } \\
\text { murabahah muncul karena } \\
\text { terjadi transaksi pembelian } \\
\text { barang dan pengukuran } \\
\text { persediaan tersebut sebesar } \\
\text { harga perolehannya }\end{array}$ \\
\hline 2. & $\begin{array}{l}\text { Piutang murabahah dicatat sebesar harga } \\
\text { jual yaitu harga perolehan ditambah } \\
\text { dengan margin/keuntungan yang sudah } \\
\text { disepakati oleh pihak nasabah dengan } \\
\text { pihak BMT } .\end{array}$ & $\begin{array}{l}\text { Pada saat akad murabahah, } \\
\text { piutang murabahah diakui } \\
\text { sebar nilai perolehan } \\
\text { ditambah keuntungan yang } \\
\text { disepakati. }\end{array}$ \\
\hline
\end{tabular}




\begin{tabular}{|c|c|c|}
\hline & $\begin{array}{l}\text { BMT Usaha Artha Sejahtera tidak } \\
\text { menggunakan rumus tertentu dalam } \\
\text { mengambil keputusan menentukan } \\
\text { margin murabahah atau tidak } \\
\text { menentukan besaran persentase margin } \\
\text { murabahah yang diambil dari harga } \\
\text { perolehan. }\end{array}$ & $\begin{array}{l}\text { Pada saat akad murabahah, } \\
\text { persentase margin } \\
\text { murabahah dihitung dengan } \\
\text { perbandingan antara margin } \\
\text { dan biaya perolehan aset } \\
\text { murabahah. }\end{array}$ \\
\hline 4. & $\begin{array}{l}\text { Apabila sebelum jangka waktu } \\
\text { pelunasan angsuran tersebut jatuh } \\
\text { tempo,nasabah melakukan pelunasan } \\
\text { dini atau percepatan pelunasan } \\
\text { pembayaran angsuran. }\end{array}$ & $\begin{array}{l}\text { Pada saat potongan } \\
\text { pelunasan }\end{array}$ \\
\hline 5. & $\begin{array}{l}\text { Apabila nasabah tidak dapat memenuhi } \\
\text { piutang murabahah sesuai yang } \\
\text { diperjanjikan maka pihak BMT tidak } \\
\text { mengenakan denda kepada nasabah } \\
\text { tetapi memberikan surat teguran } \\
\text { sebanyak tiga kali sesuai dengan } \\
\text { kebijakan pihak BMT dan diketahui } \\
\text { penyebab nasabah belum membayar } \\
\text { piutang tersebut. }\end{array}$ & $\begin{array}{l}\text { Pada saat denda dikenakan } \\
\text { jika pembeli lalai dalam } \\
\text { melakukan kewajibannya } \\
\text { sesuai dengan akad, dan } \\
\text { denda yang diterima diakui } \\
\text { sebagai dana kebajikan. }\end{array}$ \\
\hline 6. & $\begin{array}{l}\text { Pihak BMT Usaha Artha Sejahtera tidak } \\
\text { memberlakukan uang muka atas } \\
\text { murabahah yang digunakan sebagai } \\
\text { pembayaran pembelian barang. }\end{array}$ & $\begin{array}{l}\text { Pada saat akad murabahah, } \\
\text { barang diserahkan ke } \\
\text { nasabah senilai harga } \\
\text { perolehan setelah dikurangi }\end{array}$ \\
\hline
\end{tabular}




\begin{tabular}{|l|l|}
\hline & $\begin{array}{l}\text { uang muka tersebut dan } \\
\text { margin yang disepakati dan } \\
\text { diakui sebagai piutang } \\
\text { murabahah } .\end{array}$ \\
\hline
\end{tabular}

Tabel 2 Penyajian Akuntansi Murabahah

\begin{tabular}{|c|c|c|}
\hline No. & $\begin{array}{c}\text { Perlakuan Akuntansi pada BMT } \\
\text { Usaha Artha Sejahtera }\end{array}$ & $\begin{array}{c}\text { Perlakuan Akuntansi Berdasarkan } \\
\text { PSAK } 102\end{array}$ \\
\hline 1. & $\begin{array}{l}\text { Piutang murabahah tidak } \\
\text { disajikan dineraca sebesar nilai } \\
\text { bersih yang dapat direalisasi, } \\
\text { namun include (menjadi satu) } \\
\text { dengan akad piutang yang } \\
\text { lainnya sebagai piutang dan } \\
\text { pembiayaan. }\end{array}$ & $\begin{array}{l}\text { Piutang murabahah disajikan } \\
\text { sebesar nilai bersih yang dapat } \\
\text { direalisasikan, yaitu saldo piutang } \\
\text { murabahah dikurangi penyisihan } \\
\text { kerugian piutang. }\end{array}$ \\
\hline 2. & $\begin{array}{l}\text { Pihak BMT Usaha Artha } \\
\text { Sejahtera tidak menyajikan } \\
\text { margin murabahah yang di } \\
\text { tangguhkan sebagai pengurang } \\
\text { piutang murabahah, namun } \\
\text { dicatat sebagai piutang dan } \\
\text { pembiayaan. }\end{array}$ & $\begin{array}{l}\text { Margin murabahah tangguhan } \\
\text { disajikan di neraca pada bagian } \\
\text { aset dengan nama margin } \\
\text { murabahah tangguhan sebagai } \\
\text { pengurang (contra account) piutang } \\
\text { murabahah. }\end{array}$ \\
\hline 3. & $\begin{array}{l}\text { Beban murabahah yang di } \\
\text { tangguhkan tidak disajikan di } \\
\text { laporan laba/rugi, karena ketika } \\
\text { terjadi transaksi margin } \\
\text { murabahah tidak diakui atau } \\
\text { dicatat. }\end{array}$ & $\begin{array}{l}\text { Beban murabahah tangguhan } \\
\text { disajikan sebagai pengurang (contra } \\
\text { account) utang murabahah. }\end{array}$ \\
\hline
\end{tabular}




\begin{tabular}{|l|l|llr|}
\hline 4. & Margin murabahah tidak & Margin murabahah disajikan di \\
disajikan di laporan laba/rugi, & laporan laba/rugi pada bagian \\
tetapi disajikan menjadi satu & pendapatan dengan nama rekening \\
dengan akad pembiayaan yang & margin murabahah. Rekening \\
lainnya sebagai bagi hasil & margin murabahah merupakan \\
pembiayaan. & gabungan total saldo murabahah \\
akrual dan total saldo murabahah \\
kas.
\end{tabular}

Tabel 3 Pengungkapan Akuntansi Murabahah

\begin{tabular}{|c|c|c|}
\hline No. & $\begin{array}{c}\text { Perlakuan Akuntansi pada BMT } \\
\text { Usaha Artha Sejahtera }\end{array}$ & $\begin{array}{c}\text { Perlakuan Akuntansi } \\
\text { Berdasarkan PSAK } 102\end{array}$ \\
\hline 1. & $\begin{array}{l}\text { Piutang murabahah tidak } \\
\text { diungkapkan di neraca sebesar nilai } \\
\text { bersih yang dapat direalisasikan, } \\
\text { tetapi include (menjadi satu) dengan } \\
\text { akad piutang yang lainnya sebagai } \\
\text { piutang dan pembiayaan. }\end{array}$ & $\begin{array}{l}\text { Piutang murabahah } \\
\text { diungkapkan sebesar nilai } \\
\text { bersih yang dapat } \\
\text { direalisasikan, yaitu saldo } \\
\text { piutang murabahah } \\
\text { dikurangi penyisihan } \\
\text { kerugian piutang }\end{array}$ \\
\hline 2. & $\begin{array}{l}\text { Margin murabahah yang } \\
\text { ditangguhkan tidak disajikansebagai } \\
\text { pengurang piutang murabahah, } \\
\text { karena ketika terjadi transaksi margin } \\
\text { murabahah tidak diakui atau dicatat . }\end{array}$ & $\begin{array}{l}\text { Margin murabahah } \\
\text { tangguhan disajikan di neraca } \\
\text { pada bagian aset dengan } \\
\text { nama margin murabahah } \\
\text { tangguhan } \\
\text { pengurang (contra account) } \\
\text { piutang murabahah. }\end{array}$ \\
\hline 3. & $\begin{array}{l}\text { Pihak BMT tidak mengungkapkan } \\
\text { pendapatan margin murabahah, } \\
\text { tetapi disajikan jadi satu dengan akad }\end{array}$ & $\begin{array}{lrr}\text { Margin } & \text { murabahah } \\
\text { diungkapkan di } & \text { laporan } \\
\text { laba/rugi pada } & \text { bagian }\end{array}$ \\
\hline
\end{tabular}




\begin{tabular}{|l|l|l|}
\hline $\begin{array}{l}\text { pembiayaan yang lainnya sebagai } \\
\text { bagi hasil pembiayaan. }\end{array}$ & $\begin{array}{l}\text { pendapatan dengan nama } \\
\text { rekening margin murabahah. }\end{array}$ \\
\hline
\end{tabular}

\section{KESIMPULAN}

Perlakuan akuntansi murabahah pada BMT Usaha Artha Sejahtera yaitu baik pengakuan dan pengukuran, penyajian, pengungkapan belum sepenuhnya sesuai dengan PSAK 102. Saat terjadi pengakuan dan pengukuran aset murabahah tidak melakukan pengakuan aset murabahah sebesar harga perolehan barang, karena semua transaksi dilakukan dengan akad wakalah sehingga pihak nasabah sendiri yang melakukan pembelian barang atau berupa pembiayaan, BMT Usaha Artha Sejahtera tidak menggunakan rumus tertentu dalam mengambil keputusan menentukan margin murabahah atau tidak menentukan besaran persentase margin murabahah yang diambil dari harga perolehan, BMT tidak mengenakan denda kepada nasabah tetapi memberikan surat teguran sesuai dengan kebijakan pihak BMT dan diketahui penyebab nasabah belum membayar piutang tersebut, dan uang muka.

Pada saat penyajian piutang murabahah tidak disajikan dineraca sebesar nilai bersih yang dapat direalisasi, namun include (menjadi satu) dengan akad piutang yang lainnya sebagai piutang dan pembiayaan, margin murabahah tangguhan tidak disajikan sebagai pengurang piutang murabahah, namun dicatat sebagai piutang dan pembiayaan, beban murabahah tangguhan tidak disajikan di laporan laba/rugi, karena ketika terjadi transaksi margin murabahah tidak diakui atau dicatat dan margin murabahah disajikan di laporan laba/rugi, tetapi disajikan menjadi satu dengan akad pembiayaan yang lainnya sebagai bagi hasil pembiayaan.

Pada saat pengungkapan piutang murabahah tidak diungkapkan di neraca sebesar nilai bersih yang dapat direalisasikan, tetapi include (menjadi satu) dengan akad piutang yang lainnya sebagai piutang dan pembiayaan, margin murabahah tangguhan tidak diungkapkan sebagai pengurang piutang murabahah, namun dicatat sebagai piutang dan pembiayaan dan Pihak BMT 
tidak mengungkapkan margin murabahah, namun diungkapkan jadi satu dengan akad pembiayaan yang lainnya sebagai bagi hasil pembiayaan.

Transaksi keuangan yang dilakukan seharusnya diakui berdasarkan masing-masing transaksinya yaitu murabahah, mudharabah, musyarakah, ba'i bi tsaman ajil, ijarah, ba'i as-salam, isthisna dan qordhul hasan, hal tersebut menyulitkan bagi pembaca laporan keuangan jika ingin mengetahuinya sehingga membutuhkan laporan khusus yang dibuat oleh pihak BMT apabila ingin mengetahui pada masing-masing transaksi.

\section{IMPLIKASI PENELITIAN}

Implikasi Pada penelitian ini yaitu penyajian piutang murabahah tidak disajikan di neraca sebesar nilai bersih yang dapat direalisasikan, tetapi menjadi satu dengan akad piutang yang lainnya sebagai piutang dan pembiayaan, margin murabahah tangguhan tidak diungkapkan sebagai pengurang piutang murabahah, namun dicatat sebagai piutang dan pembiayaan dan pihak BMT tidak mengungkapkan margin murabahah, namun diungkapkan jadi satu dengan akad pembiayaan yang lainnya sebagai bagi hasil pembiayaan.

\section{REFERENSI}

Albana, M. S., \& Firmansyah, A. (2021). Implementasi Akuntansi Murabahah Pada Pembiayaan Bsm Oto Di Bank Syariah Mandiri: Apakah Sesuai Dengan PSAK 102? Jurnal Ekonomi Syariah Teori Dan Terapan, 8(2), 193-202. https:// doi.org/10.20473/vol8iss20212pp193-202

Ardha, N. B. D., \& Rahman, A. F. (2013). Analisis Perlakuan Akuntansi Murabahah Pada PT Bank Rakyat Indonesia Syariah Syariah Cabang Kota Malang. Jurnal Universitas Brawijaya Malang.

Ernawati, L. (2020). Analisis Penerapan Akuntansi Murabahah Berdasarkan PSAK 102 (Studi Kasus BMT Maslahah Cabang Pembantu Diwek). 2, 76-89.

Fasiha. (2015). Akad Murabahah Dan Permasalahannya Dalam Penerapan Di LKS. Jurnal Muamalah, V(1), 11-19.

Hidayah, N., Sriwardany, \& Haidir. (2021). Analisis Perlakuan Akuntansi 
Syariah untuk Pembiayaan Murabahah serta Kesesuaiannya dengan PSAK No. 102 pada PT Bank BNI Syariah Cabang Pembantu Katamso. Jurnal Akrab Juara, 6(3), 226-236.

Latifah, E. (2021). Kesesuaian Perlakuan Akuntansi Murabahah Dengan PSAK Syariah No. 102 Pada Islamic Microfinance Intitutions. Al-Musthofa: Journal of Sharia Economics, 4, 105-119. http://ejournal.iaitabah.ac.id/index.php/musthofa/article/view/731

Mughni, J. A. (2019). Analisis Penerapan Akuntansi Syariah Berdasarkan PSAK Nomor 102 pada Pembiayaan Murabahah di BMT Al-Ittihad Cikurubuk Tasikmalaya. Eco-Iqtishodi: Jurnal Ilmiah Ekonomi Dan Keuangan Syariah, 1(1), $1-10$.

Nasir, S. M., \& Sululing, S. (2015). Penerapan Akuntansi Murabahah Terhadap Pembiayaan Kredit Pemilikan Rumah Pada Bank Syariah Mandiri Cabang $\begin{array}{llll}\text { Luwuk. Jurnal } & \text { 109-128. }\end{array}$ https:// doi.org/10.24912/ja.v19i1.117

Novianti, Ahmad, I. H., \& Indriyani, N. (2020). Analisis Perlakuan Akuntansi Murabahah Pada PT Bank Pembangunan Daerah Sulselbar Cabang Syariah Makassar. Accounting Journal, 01(02), 1-8. http://ojs.stkipypup.ac.id/index.php/SA/article/view/277\%0Ahttp://ojs.stkipypup.ac.id/index.php/SA/article/download/277/257

Oktafiya, Z. N., \& Iswanaji, C. (2020). Menyibak Penerapan PSAK 102 Atas

Prosedur Akad Murabahah (Studi Kasus Pada KSPPS BMT ARMA Magelang). Jurnal Akuntansi Syariah, 4(2), 154-161.

Parno, \& Tikawati. (2016). Analisis Penerapan PSAK No. 102 Untuk Pembiayaan Murabahah Pada KPN IAIN Samarinda. El-Jizya: Jurnal Ekonomi Islam, 4(2), 285-316. https://doi.org/10.24090/ej.v4i2.2016.pp285316

Pratiwi, I. E., \& Septiarini, D. F. (2014). Analisis Penerapan PSAK 102 Murabahah (Studi Kasus pada KSU BMT Rahmat Syariah Kediri). AKRUAL Jurnal Akuntansi, 6(1), 17-32. 
Purnama, D. H., \& Putra, A. D. (2018). Analisis Transaksi Murabahah Berdasarkan Fatwa DSN-MUI No. 04/DSN-MUI/IV/2000 dan Standar Akuntansi Syariah (PSAK 102 dan AAOIFI FAS 2) di PT Bank Syariah Mandiri. Ekobis: Jurnal Ekonomi Dan Bisnis Syariah, 2(2), 45-54.

Putri, B. A. A., \& Praptoyo, S. (2020). Mekanisme Dan Perlakuan Akuntansi Pembiayaan Murabahah Berdasarkan Psak No. 102. Jurnal Ilmu Dan Riset Akuntansi, 9(11), $1-14$. http://jurnalmahasiswa.stiesia.ac.id/index.php/jira/article/view/3712

Rosiyana, T., Jubaedah, S., \& Astuti, A. D. (2022). Analisis Akuntansi Murabahah pada UJKS BMT Al-Islah Cirebon. Medikonis: Jurnal Media Komunikasi Dan Bisnis, 13(1), 1-19.

Sahara, M. A., \& Rahmasari, Y. (2018). Analisis Pelaksanaan Akuntansi Syariah untuk Pembiayaan Murabahah serta Kesesuaiannya terhadap PSAK No 102 pada PT BPRS Syarikat Madani Tanjungpinang. CASH, 1(02), 39-51.

Septyarini, D. N. (2018). Analisis Akuntansi Murabahah pada Divisi Unit Usaha Syariah (UUS) BPD Kalimantan Timur. Ekonomia, 6(3), 5-24.

Susilowati, D., \& Sofi'i, I. (2018). Analisis Penerapan PSAK 102 Untuk Akad Murabahah Dalam Pembiayaan Kepemilikan Rumah pada PT Bank BJB Syariah KCP Tangerang. Proseding Seminar Nasional Akuntansi, 1(1). http://openjournal.unpam.ac.id/index.php/SNU/article/viewFile/956/7 87

Wardani, P. E. (2017). Analisis Penerapan PSAK 102 atas Pembiayaan Murabahah (Studi Kasus Pada Bank Mandiri Syariah). Jurnal Ilmiah Riset Akuntansi, 6(4), 17-35.

Yusuf, M. (2013). Analisis Penerapan Pembiayaan Murabahah Berdasarkan Pesanan dan Tanpa Pesanan serta Kesesuaian dengan PSAK 102. Binus Business Review, 4(1), 15-29. https:// doi.org/10.21512/bbr.v4i1.1032 